\title{
Foscarnet Decreases Human Immunodeficiency Virus RNA
}

\author{
Laurent Kaiser, Luc Perrin, Bernard Hirschel, \\ Hansjakob Furrer, Jan Von Overbeck, Maya Olmari, \\ and Sabine Yerly
}

Division of Infectious Diseases, Central Laboratory of Virology, University Hospital. Geneva, and Medical Policlinic, University Hospital, Bern, Switzerland

Foscarnet inhibits human immunodeficiency virus (HIV) replication in vitro and decreases p24 antigenemia in patients with cytomegalovirus (CMV) retinitis. To evaluate the effect of foscarnet on HIV replication, HIV RNA was quantitated in 17 patients before and during foscarnet therapy. Fifteen patients had CMV retinitis, 1 had CMV encephalitis, and 1 had intractable zoster. A decrease in HIV RNA was observed in 16 of 17 patients. Before the introduction of foscarnet, mean HIV RNA was $5.82 \pm 0.24 \log$ RNA/mL and, after a median of 13 days of therapy, mean HIV RNA was $5.30 \pm 0.27 \log \mathrm{RNA} / \mathrm{mL}(P<.001)$. Among patients with detectable $\mathrm{p} 24$ antigen at baseline, a significant decrease was observed $(P=.017)$. This decrease in HIV RNA demonstrates that foscarnet is a potent antiretroviral drug.

Foscarnet (sodium salt of phosphonoformic acid) is, in vitro, a noncompetitive inhibitor of human immunodeficiency virus (HIV) reverse transcriptase and decreases HIV replication [1, 2]. In AIDS patients treated with foscarnet for cytomegalovirus (CMV) retinitis, a decrease in p24 antigenemia was observed, suggesting an inhibition of HIV replication in vivo [3, 4]. In a large randomized study comparing foscarnet with ganciclovir for the treatment of $\mathrm{CMV}$ retinitis, the effect on retinitis was similar, but patients treated with foscarnet survived longer, leading to speculation that foscarnet's anti-HIV effect might be of clinical importance [5]. In view of these data, we quantitated HIV viremia before and during foscarnet therapy to assess the effect of foscarnet on HIV load.

\section{Patients and Methods}

Study population. AIDS patients with CMV disease whose physicians decided to use foscarnet were enrolled retrospectively and prospectively. Among patients enrolled prospectively, viremia was measured using serum samples collected on day 0 (before starting foscarnet) and after 10 days of treatment. Patients were enrolled retrospectively if frozen serum samples were available between -10 and 0 days and between 10 and 30 days after the initiation of foscarnet.

Quantitation of HIV RNA, p24 antigen, and $C D 4^{+}$cell counts. Blood was collected without anticoagulant, centrifuged twice for $5 \mathrm{~min}$ at $1500 \mathrm{~g}$, aliquoted, and stored at $-75^{\circ} \mathrm{C}$, all within $2 \mathrm{~h}$. Total RNA from $50 \mu \mathrm{L}$ of serum was extracted using an automated system (Autogen 540; Autogen Instrument, Beverly, MA). RNA purification was based on the single-step method of acid guanidinium thiocyanate-phenol-chloroform extraction [6].

Received 29 December 1994; revised 21 February 1995.

Reprints or correspondence: Dr. Sabine Yerly, Central Laboratory of Virology, Geneva University Hospital, CH-1211 Geneva 14, Switzerland.

The Journal of Infectious Diseases $1995 ; 172: 225-7$

(C) 1995 by The University of Chicago. All rights reserved.

0022-1899/95/7201-0032\$01.00
Circulating HIV RNA was quantitated in relation to an external standard, as previously described $[7,8]$. Briefly, total RNA recovered from $50 \mu \mathrm{L}$ of serum was reverse transcribed, and a 238 -bp sequence of a conserved region of the pol gene was amplified by polymerase chain reaction. The intra- and interassay variations were $11 \%$ and $25 \%$, respectively (data not shown). To eliminate interassay variation, samples from the same patient were assayed in the same experiment. Viremia was expressed as logarithm of HIV RNA copies per milliliter of serum.

$\mathrm{CD}^{+}$cell counts were determined by flow cytometry (Coulter EPICS IV; Instrumente Gesellschaft, Basel, Switzerland) using fluoresceinated DAKO-T3, DAKO-T8, and R-phycoerythrin DAKO-CD4 (Dako, Glostrup, Denmark). p24 antigen levels were measured in duplicate using batch testing (HIVAG-1; Abbott Laboratories, Abbott Park, IL).

\section{Results}

Seventeen patients were enrolled in this study: 7 retrospectively and 10 prospectively between January and October 1994. Fifteen patients had CMV retinitis (4 relapsed during maintenance therapy with ganciclovir), 1 had CMV encephalitis, and 1 had intractable disseminated zoster. The median $\mathrm{CD} 4^{+}$cell count was $24 / \mathrm{mm}^{3}$ (range, 1-202), and all patients were diagnosed with AIDS before the introduction of foscarnet. Eight patients had been receiving antiretroviral treatment for $>4$ weeks at the time of CMV disease; 6 were receiving didanosine and 2 were receiving zidovudine. For 2 patients, didanosine was stopped the day foscarnet was introduced, whereas the others continued to receive didanosine or zidovudine at identical dosages (table 1). For the 9 remaining patients, antiretroviral therapy was stopped for at least 10 weeks. Sixteen patients received $9.0-13.5 \mathrm{~g} /$ day of foscarnet, depending on body weight; 1 patient received $6 \mathrm{~g} /$ day because of renal failure.

A decrease in HIV RNA was observed during foscarnet therapy in all but 1 patient (table 1). At baseline, the mean ( \pm SE) HIV RNA was $5.82 \pm 0.24 \log \mathrm{RNA} / \mathrm{mL}$. After a median of 13 days of therapy, the mean HIV RNA level was $5.30 \pm 0.27 \log \mathrm{RNA} / \mathrm{mL}$. A statistically significant mean de- 
Table 1. Quantitation of human immunodeficiency virus (HIV) RNA and p24 antigen in 17 patients before and during foscarnet therapy.

\begin{tabular}{|c|c|c|c|c|c|c|}
\hline \multirow[b]{2}{*}{ Patients } & \multirow[b]{2}{*}{$\begin{array}{l}\text { Concomitant } \\
\text { antiretroviral* }\end{array}$} & \multirow[b]{2}{*}{$\begin{array}{c}\text { Baseline } \mathrm{CD}^{+} \\
\text {cells } / \mathrm{mm}^{3}\end{array}$} & \multicolumn{2}{|c|}{ Log HIV RNA/mL } & \multicolumn{2}{|c|}{ p24 antigen (ng/L) } \\
\hline & & & $\begin{array}{c}\text { Before } \\
\text { foscarnet }^{\dagger}\end{array}$ & $\begin{array}{c}\text { After } \\
\text { foscarnet }^{\ddagger}\end{array}$ & $\begin{array}{c}\text { Before } \\
\text { foscarnet }^{\dagger}\end{array}$ & $\begin{array}{c}\text { After } \\
\text { foscarnet }^{\ddagger}\end{array}$ \\
\hline 1 & No & 40 & 5.47 & 4.67 & 52 & $\mathrm{Neg}$ \\
\hline 2 & ddI & 79 & 6.58 & 5.67 & 284 & 188 \\
\hline 3 & $\mathrm{No}^{8}$ & 19 & 5.97 & 5.89 & Neg & 12 \\
\hline 4 & ddI & 1 & 3.86 & 3.45 & 7 & $\mathrm{Neg}$ \\
\hline 5 & $\mathrm{No}^{8}$ & 45 & 4.00 & 3.64 & 172 & 72 \\
\hline 6 & ddI & 6 & 4.61 & 4.35 & Neg & Neg \\
\hline 7 & No & 36 & 6.23 & 6.04 & 63 & 26 \\
\hline 8 & No & 2 & 4.61 & 3.85 & 5 & 13 \\
\hline 9 & No & 1 & 6.54 & 6.32 & 14 & 4 \\
\hline 10 & No & 89 & 5.82 & 5.04 & 36 & 9 \\
\hline 11 & No & 24 & 6.48 & 6.88 & 6 & 8 \\
\hline 12 & No & 30 & 6.59 & 6.22 & Neg & Neg \\
\hline 13 & ddI & 2 & 6.74 & 6.46 & 5 & 15 \\
\hline 14 & No & 79 & 6.80 & 6.32 & 139 & 13 \\
\hline 15 & $\mathrm{AZT}$ & 4 & 5.66 & 4.17 & 33 & 11 \\
\hline 16 & $\mathrm{AZT}$ & 202 & 6.40 & 4.87 & 5731 & 386 \\
\hline 17 & No & 2 & 6.61 & 6.21 & $\mathrm{Neg}$ & $\mathrm{Neg}$ \\
\hline
\end{tabular}

NOTE. All patients had cytomegalovinus (CMV) retinitis, except patients 14 (disseminated zoster) and 15 (CMV encephalitis). ddI, didanosine; AZT, zidovudine; neg, negative.

* In 6 patients, antiretroviral treatment with nucleoside analogues was continued during foscarnet therapy.

${ }^{\dagger} 0-10$ days before foscarnet.

$\ddagger$ After 10 days of foscamet.

$\S$ Received ddI until start of foscarnet.

crease of $0.53 \pm 0.12 \log \mathrm{RNA} / \mathrm{mL}$ was observed during therapy (paired $t$ test, $P<.001$ ). A decrease in HIV RNA of $>0.7$ $\log (>80 \%)$ was seen in 6 of 17 patients and a decrease of $>0.3 \log (>50 \%)$ in 11 patients. One patient had an increase in HIV RNA.

Of 13 patients who were p 24 antigen-positive at baseline (range, 5-5531 ng/L), 10 had decreased levels (range, -34\% to $-100 \%$ ) during therapy (table 1) that were statistically significant (Wilcoxon paired test, $P=.017$ ). Of the 4 patients who were p24 antigen-negative at baseline, 3 remained negative and 1 became positive.

Median survival after the diagnosis of CMV disease or zoster was 5 months (range, $1-13$ ).

\section{Discussion}

Ganciclovir and foscarnet are equally efficacious for the treatment of CMV retinitis $[5,9,10]$. However, foscarnet has the potential advantage of also inhibiting HIV replication. Foscarnet decreases p24 antigen levels [3, 4], but no data on the impact of foscarnet therapy on HIV viremia are available. Our results show that foscarnet has a measurable effect on HIV RNA in patients with CMV disease. The decrease of HIV RNA observed in our 17 patients is significant and comparable to that observed with other antiretroviral drugs $[7,8,11,12]$.
Moreover, this effect was observed in patients previously treated for several years with nucleoside analogues. In vitro data suggest that the inhibition of HIV replication by foscarnet and zidovudine is synergistic $[1,2]$. In our study, it is interesting that the 2 patients receiving zidovudine during foscarnet treatment had the largest decrease in HIV viremia $(-1.49$ and $-1.53 \log \mathrm{RNA} / \mathrm{mL}$ ).

As reported previously $[3,4]$, we also observed a decrease in p24 antigen level. However, p24 antigen was not detectable at baseline in all patients. Moreover, in 3 patients with low p24 antigenemia ( $<15 \mathrm{ng} / \mathrm{L}$ ), a weak elevation in p24 antigen level was observed, which did not correlate with the substantial decrease seen in HIV RNA. Slight variations of p24 antigenemia might be the result of variations in the production of antip24 antibodies over time. In this context, our results highlight the advantages of measuring HIV RNA, which is detectable in all patients and is a more accurate marker of HIV replication.

The median survival reported in our study was 5 months, which is lower than that in some prospective therapeutic studies [5]. However, we recruited patients regardless of clinical situation, associated comorbidities, or prognosis. Most of our patients had a history of multiple AIDS-defining events, and some had other active opportunistic infections, thus explaining the high mortality.

For patients with CMV retinitis, foscarnet's activity against HIV is an appealing side effect, perhaps resulting in increased 
survival [5]. Unfortunately, the drug needs to be administered intravenously and has numerous dose-dependent adverse effects. It is unlikely, therefore, that high doses will ever be used against HIV in patients without CMV disease or intractable herpes. The effects on HIV of lower doses and possible synergy with other antiretrovirals are interesting subjects for further studies.

\section{Acknowledgments}

We thank $W$. Caveng for excellent technical assistance and J.-F. Balavoine for his support in patient enrollment.

\section{References}

1. Koshida R, Vrang L, Gilljam G, Harmenberg J, Oberg B, Wahren B. Inhibition of human immunodeficiency virus in vitro by combinations of $3^{\prime}$-azido- $3^{\prime}$-deoxythymidine and foscarnet. Antimicrob Agents Chemother 1989; 33:778-80.

2. Eriksson BF, Schinazi RF. Combinations of 3'-azido-3'-deoxythymidine (zidovudine) and phosphonoformate (foscarnet) against human immunodeficiency virus type 1 and cytomegalovirus replication in vitro. Antimicrob Agents Chemother 1989;33:663-9.

3. Reddy MM, Grieco MH, McKinley GF, et al. Effect of foscarnet therapy on human immunodeficiency virus p24 antigen levels in AIDS patients with cytomegalovirus retinitis. J Infect Dis 1992;166:607-10.

4. Fletcher CV, Collier AC, Rhame FS, et al. Foscarnet for suppression of human immunodeficiency virus replication. Antimicrob Agents Chemother 1994;38:604-7.
5. Studies of Ocular Complications of AIDS Research Group, in collaboration with AIDS Clinical Trials Group. Mortality in patients with the acquired immunodeficiency syndrome treated with either foscarnet or ganciclovir for cytomegalovirus retinitis. N Engl J Med 1992;326:213-20.

6. Chomczynski P, Sacchi N. Single-step method of RNA isolation by acid guanidinium thiocyanate-phenol-chloroform extraction. Anal Biochem 1987; 162:156-9.

7. Yerly S, Kaiser L, Baumberger C, Hirschel B, Perrin L. Early and prolonged decrease of viremia in HIV-1 infected patients treated with didanosine. J Acquir Immune Defic Syndr 1995; 8:358-64.

8. Yerly S, Kaiser L, Mermillod B, Baumberger C, Hirschel B, Perrin L. Response of HIV RNA to didanosine as predictive marker of survival. AIDS 1995;9:159-63.

9. Jacobson MA, Wulfsohn M, Feinberg JE, et al. Phase Il dose-ranging trial of foscarnet salvage therapy for cytomegalovirus retinitis in AIDS patients intolerant of or resistant to ganciclovir (ACTG protocol 093). AIDS Clinical Trials Group of the National Institute of Allergy and Infectious Diseases. AIDS 1994;8:451-9.

10. Jacobson MA, Kramer F, Bassiakos $Y$, et al. Randomized phase I trial of two different combination foscarnet and ganciclovir chronic maintenance therapy regimens for AIDS patients with cytomegalovirus retinitis: AIDS clinical Trials Group Protocol 151. J Infect Dis 1994; 170:189-93.

11. Katzenstein DA, Winters M, Bubp J, Israelski D, Winger E, Merigan TC. Quantitation of human immunodeficiency virus by culture and polymerase chain reaction in response to didanosine after long-term therapy with zidovudine. J Infect Dis 1994; 169:416-9.

12. Katlama C, European Lamivudine HIV working group. Combination 3TC (lamivudine)/ZDV (zidovudine) vs. ZDV monotherapy in ZDV naive HIV-1 positive patients with CD4 of $100-400$ cells $/ \mathrm{mm}^{3}$. AIDS 1994; 8(suppl 4):S6. 